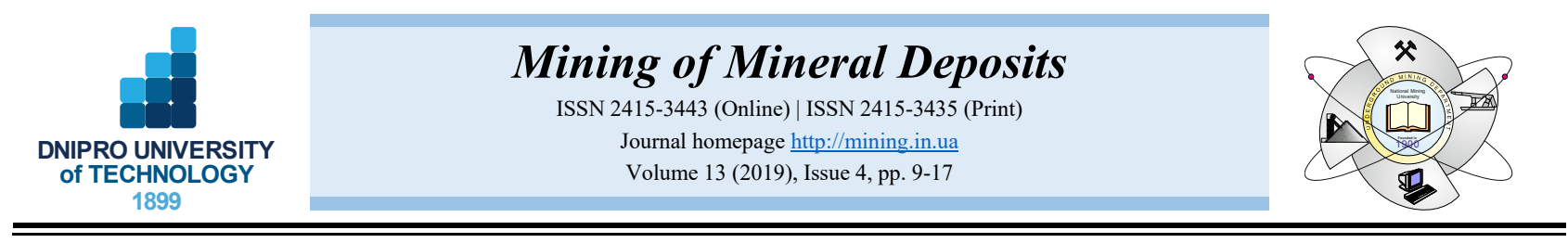

\title{
FORECAST OF POTENTIALLY DANGEROUS ROCK PRESSURE MANIFESTATIONS IN THE MINE ROADWAYS BY USING INFORMATION TECHNOLOGY AND RADIOMETRIC CONTROL METHODS
}

\author{
I. Slashchov ${ }^{1 *}$, V. Shevchenko ${ }^{1}$, V. Kurinnyi ${ }^{2}$, O. Slashchova ${ }^{1}$, O. Yalanskyi ${ }^{2}$ \\ ${ }^{1}$ Institute of Geotechnical Mechanics named by N. Poljakov of National Academy of Sciences of Ukraine, Dnipro, Ukraine \\ ${ }^{2}$ Dnipro University of Technology, Dnipro, Ukraine \\ *Corresponding author: e-mail IMSlashchov@nas.gov.ua, tel. +380677260767
}

\begin{abstract}
Purpose. To reduce risk of emergency and injury-risk situations while improving the methods for predicting stressstrain state of the rock mass with the help of information systems, and to detect fissure locations in the mine roadways with the help of radiometric control.

Methods. Analysis and generalization of experimental data; mathematical modeling of geomechanical and filtration processes by means of the finite element method; underground investigations of changes in activity of $\alpha$-radiation of certain radon-isotope in the atmosphere of the mine roadways using standard methods as well as radiometric control equipment; and statistical processing of measurement results.

Findings. Ratios, determining correlation between parameters of geomechanical process (i.e. fracture porosity, inclination angles of the fracture networks and their strike) and parameters of gas- dynamic process (i.e. intensity, gas flow rates and direction of gas travel) have been obtained. A mathematical model based on the finite element method is proposed in which a reasonable assumption is made that deformation of the pore medium is equal to the varied volume of the pore and fracture area. In the context of the model, deviation part of the strain tensor determines changes in the shape of the rock mass elements during disintegration. Spherical part of the strain tensor characterizes changes in volume and permeability of the pore and fracture area; it is determined by a value of minimum principal strains of the model elements. Parameters of the pore and fracture area location, volume and permeability were substantiated in the rock mass. The mine investigations have helped determine that within the areas of geological dislocations, concentration of radon daughter decay product of alpha-radiation polonium $\left(\mathrm{Po}^{218}\right)$ experiences more that $2-4$ times increase in relation to the roadway average value. On the basis of the criterion, it is proposed to use radiation monitoring of the mine roadways to identify areas of newly formed fracture systems resulting from fracture system deformation as one of the elements of method for the integrated control of the rock mass state.
\end{abstract}

Originality. For the first time, regularities of changes in the pore and fracture area shape and volume at different stages of the adjacent longwall mining have been determined basing on parameters of technogenic fracture system orientation and spherical part of the strain tensor. The method of controlling the safe state of rocks has been further developed; it differs in the use of the determined ratios between changes in fracture system parameters and changes in $\alpha$-radiation activity of some radon isotopes, methane concentrations and their correlation.

Practical implications. The research results have been applied for the development of analytical and experimental approach to control safety of production environment in mines.

Keywords: geomechanical processes, permeability, filtration, radiation monitoring, rock mass modeling, forecast of geomechanical state

\section{INTRODUCTION}

Geotechnological systems in mines pose a risk to workers due to certain negative factors observed in the underground roadways. Statistics show that only in 2017, injuries caused by rock fall, inrush and bumps, and gas and dust explosions accounted for $47 \%$ of the total number of victims $(33 \%$ caused by rock falls and $12 \%$ - by gas and dust explosions (Ministry of Energy and Coal Industry of Ukraine, 2018). At the same time, coefficient of fatal cases in the industries increased to 4.6 people per one million tons of the mined coal. Material costs are also significant

(C) 2019. I. Slashchov, V. Shevchenko, V. Kurinnyi, O. Slashchova, O. Yalanskyi. Published by the Dnipro University of Technology on behalf of Mining of Mineral Deposits. This is an Open Access article distributed under the terms of the Creative Commons Attribution License (http://creativecommons.org/licenses/by/4.0/),

which permits unrestricted reuse, distribution, and reproduction in any medium, provided the original work is properly cited. 
(Shevchenko, 2016). Experience of underground mining activity has shown that as a result of intensification of the rock displacement processes, the roadway cross sections decrease, and methane gas flows intensively into the mine atmosphere, necessitating substantial increase in the expenditure to restore supporting systems in the mine roadways and increase in the air flow for proper ventilation.

Manifestations of rock pressure in the mine roadways can be predicted by assessing changes in rock stressstrain state with the help of computer systems (Bulat \& Slashchov, 2012; Slashchov, 2016). That technology to study complex objects and processes includes computational experiment, which is based on computer construction and analysis of mathematical models. Components of the technology are mathematical dependences and software tools, while the research process consists of well-scheduled sequence of operations with data and actions with different degrees of complexity. At the same time, in order to solve complex geomechanical problems, it is necessary to look into uncertainties caused by different structures of rock layers bedding, instability of elastic and strength properties, initial fracturing pattern, geological disturbance, gas and water saturation etc. In addition to analytical studies, that requires carrying out a series of full-scale underground experiments to verify models and refine the calculated data.

As a promising technique for mine monitoring, a radiometric method can be used, which is based on identification of space and time variations of radon decay product exhalation in the underground roadways. This method makes it possible to detect hidden tectonic dislocations and stress concentration in the rock mass, which cannot be detected by any other methods. Therefore, risk of emergency and traumatic situations can be reduced by predicting geomechanical and gas-dynamic states of the rock mass with the help of the latest information technology, online radiometric monitoring of the rock state parameters, and development of practical measures to prevent accidents and improve safety of geotechnical system.

\section{METHODS}

Prediction of the potentially dangerous manifestations of rock pressure in the mine roadways is possible only if you know mathematical relationships, which establish links between the required parameters and the initial conditions and parameters of the system under the study. Explicit mathematical dependences for such a complex system are of little use; therefore, the methodology of simulation modeling by the finite element method and the initial stress method was adopted for the research (Gallager, 1984; Fadeyev, 1987; Slashchov, 2013; Zienkiewicz, Taylor, \& Zhu, 2005). Initial parameters for physical and mechanical properties of the watered gassaturated rock mass are presented in (Slashchova, Slashchov, \& Yalanskiy, 2014; Yalanskiy, Sapunova, Slashchov, \& Novikov, 2014; Ikonnikov, Ikonnikov, Slashchova, Slashchov, \& Yalanskiy, 2015). Mathematical modeling of geomechanical and gas-seepage processes with the help of finite element method was carried out by using the computing complex $\left(\right.$ GEO-RS ${ }^{\odot}$ computing complex development and software implementation of the system functions were carried out on the basis of studies conducted by the (Bulat \& Slashchov, 2012; Slashchov, Shevchenko, \& Slashchov, 2013; Bulat, Slashchov, \& Slashchova, 2017).

Parameters of changes in radon-isotope $\alpha$-radiation activity in the mine roadways atmosphere were monitored during the underground research with the help of the radiometer (RGA-09 $\mathrm{MSH}^{\odot}$ radon radiometer) (Bulat et al., 2013; Bulat, Slashchov, \& Slashchova, 2014). Procedure of measurements included: sampling of aerosols from the air by pumping air through the filter; registration of $\alpha$-radiation of Radon Decay Product aerosols accumulated on the filter; calculation of radon equivalent equilibrium volume activity by Markov's method.

\section{RESULTS AND DISCUSSION}

\subsection{Conditions for the activation of gas-dynamic processes in the rock mass}

Initial conditions for the gas-dynamic process activation around the mine roadways can be represented as two main groups of factors. The first group is determined by the availability and parameters of gas emission sources, which, in our case, are represented as flat and annular contours (Fig. 1).

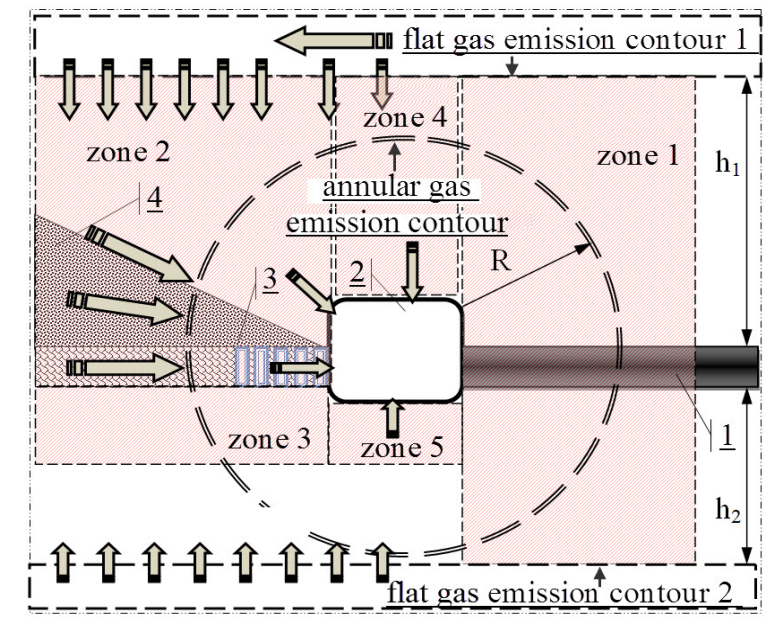

Figure 1. Scheme to calculate geomechanical and gasdynamic parameters in the layered rock mass around the mine roadways in areas of adjacent longwall conjunction: 1-coal seam; 2-mine roadway; 3-elements of supporting structures; 4 -goaf; zone 1 -zone of high rock pressure (with low permeability); zones 2,3 -release zones in the roof (with high permeability) and floor of the coal seam under development, respectively; zones 4,5 release zones in the roof and floor of preparatory roadways; $R$-radius of the annular release zone; $h_{1}, h_{2}$ - distances to the flat gas emission contour in the roof and floor of the mine roadways

Here, gas emission contours are understood as lines where gas pressure either remains constant or varies according to a certain law that does not depend on the rate of gas flow from the gas-bearing formation or other gas sources. The second group of factors is determined by rock permeability along the gas seepage path into the roadway as well as by pressure difference in the gas flow gallery and gas emission contour within the studied intervals. 
For flat gas emission contours, volume flow rate of the seeping gas flow in the rock mass, taking into account turbulence and additional losses, can be determined by Darcy law for the average pressure $\left(p_{1}+p_{2}\right) / 2$ in the gas flow in the following form:

$Q=\frac{K F}{\mu}\left(\frac{p_{2}^{2}-p_{1}^{2}}{2 l p_{1}}\right), \mathrm{m}^{3} / \mathrm{s}$,

where:

$Q-$ gas flow, $\mathrm{m}^{3} / \mathrm{s}$

$K$-permeability coefficient for the pore-fractured area, $\mathrm{m}^{2}$;

$F$ - area of the flow cross section, $\mathrm{m}^{2}$;

$\mu$-dynamic viscosity of the seeping gas, $\mathrm{Pa} \cdot \mathrm{s}$;

$l$ - length of the gas-seepage path, $\mathrm{m}$;

$p_{1}, p_{2}-$ pressure in the sections at the beginning and in the end of the interval, respectively, $\mathrm{Pa}$.

For annular gas emission contours, volume flow in the release area with radius $r$ and with radius of annular release contour $R$ can be calculated by J. Dupuis formula. In case of flat-radial steady-state flow (dynamic viscosity of the gas is ignored for practical calculations), integral form of Darcy law is as follows:

$Q=\frac{\pi h K}{\mu} \cdot \frac{\left(p_{2}^{2}-p_{1}^{2}\right)}{p_{a} \ln \frac{R}{r}}, \mathrm{~m}^{3} / \mathrm{s}$,

where:

$h$ - thickness of permeable layer, $\mathrm{m}$;

$p_{1}, p_{2}$ - seam pressure on the rectilinear flow gallery and gas emission contour within the interval, respectively, $\mathrm{Pa}$;

$p_{a}-$ atmospheric pressure, $\mathrm{Pa}$.

As it can be seen from equations (1) and (2), geomechanical process of the rock inelastic strain is associated with the volume gas flows in the rock mass by the parameters of pore-fractured area and pressure gradients, which are the most important characteristics of the gasdynamic process.

Pore-fractured area can be represented as a network of connected pores, as well as cracks of natural and technogenic origin. Natural porosity and fracturing are determined at the stage of exploratory drilling by laboratory tests, and they are known for most of the rocks in the producing deposits. Technogenic cracks experience their development during the process of mining activity as a result of deformation processes. The overwhelming majority of natural and technogenic cracks are united into the oriented systems, which walls can be considered as planes resisting the gas flow due to the friction forces. Therefore, dependence of rock permeability on fracture porosity and rate of crack opening can be obtained with the help of Boussinesq equation:

$q=\frac{b_{T}^{3} l_{T}}{12 \mu} \cdot \frac{d p}{d x}, \mathrm{~m}^{3} / \mathrm{s}$,

where:

$$
\begin{aligned}
& q-\text { gas flow per slot length, } \mathrm{m}^{3} / \mathrm{s} \\
& b_{T}-\text { crack opening, } \mathrm{m} ; \\
& l_{T}-\text { length of cracks, } \mathrm{m} ; \\
& d p / d x-\text { is pressure gradient, } \mathrm{Pa} / \mathrm{m} \text {. }
\end{aligned}
$$

Represent the length of cracks in the area of seepage surface as the fracture porosity and opening of the fracture system $b$ under the condition that $b_{T}=$ const $=b$ :

$l_{T}=\frac{m_{T} F}{b}, \mathrm{~m}$,

where:

$m_{T}$ - fracture porosity, in relative units;

$b$ - opening of the fracture system, $\mathrm{m}$.

By substituting (4) into (3), we obtain the gas flow rate in the rocks through the cross-sectional area of the gas flow:

$Q=\frac{m_{T} F b^{2}}{12 \mu} \cdot \frac{d p}{d x}, \mathrm{~m}^{3} / \mathrm{s}$.

By successively equating right sides of the equations (1), (2), and (5), we obtain relationship between coefficients of seepage through the fractures and fracture porosity:

$k_{T}=\frac{m_{T} b^{2}}{12}, \mathrm{~m}^{2}$

as well as expressions to calculate rate of gas flow through the fractured mass, taking into account its stressstrain state, when the cracks are perpendicular to the seeping surface:

- for the flat gas emission contours:

$Q=\frac{\left(m+m_{T} b^{2}\right) F}{24 l \mu}\left(\frac{p_{2}^{2}-p_{1}^{2}}{p_{1}}\right), \mathrm{m}^{3} / \mathrm{s} ;$

- for the annular gas emission contours:

$Q=\frac{\left(m+m_{T} b^{2}\right) \pi h}{12 \mu \ln \frac{R}{r}}\left(\frac{p_{2}^{2}-p_{1}^{2}}{p_{a}}\right), \mathrm{m}^{3} / \mathrm{s}$,

where:

$m$ - natural porosity in relative units.

Permeability of fractured rocks depends on fracture system strike and direction of gas seeping. The greatest loss of flow energy occurs when it moves across the dominant systems of cracks and stratification of rocks. For an arbitrary location of the fracture system, model of gas flow will be determined by the relationships:

- for the flat gas emission contours:

$Q=\frac{\left(m+m_{T} b^{2}\right)\left(\sin ^{2} \omega \cos ^{2} \theta+\cos ^{2} \omega\right) F}{24 l \mu}\left(\frac{p_{2}^{2}-p_{1}^{2}}{p_{1}}\right)$

- for the annular gas emission contours:

$Q=\frac{\left(m+m_{T} b^{2}\right)\left(\sin ^{2} \omega \cos ^{2} \theta+\cos ^{2} \omega\right) \pi h}{12 \mu \ln \frac{R}{r}}\left(\frac{p_{2}^{2}-p_{1}^{2}}{p_{a}}\right)$,

where:

$\omega$ - angle of the fracture system incidence, deg;

$\theta$ - angle between the direction of gas seepage and the fracture system strike, deg. 
The obtained relationships (9), (10) establish interdependence between the geomechanical process parameters (fracture porosity, angles of fracture system incidence, and strike) and parameters of gas-dynamic process (intensity, flow rates, and direction of gas flow); they are valid both for the flat and annual gas-emission contours and can be integrated into information systems for preventive control of production environment in the mines. Prediction of geomechanical and gas-dynamic process parameters makes it possible to calculate probability of the occurrence of hazardous factors (it is the basic parameter for mine safety systems), warn personnel, and take measures to prevent adverse events.

\subsection{Prediction of pore-fractured area volumes in the rock mass}

Permeability parameters depend greatly on the rock disintegration degree (opening of pores and cracks) and orientation of gas seepage paths in the geospace. Changes in pressure gradients within the rock mass depend on the conditions of roadways driving and supporting; they can be determined analytically by assessing the rock mass stress-strain state with the help of the latest information systems (Bulat \& Slashchov, 2012; Slashchov, 2013).

In order to assess changes in the pore-fractured area parameters, patterns of rock deformation changing around the mine roadways can be used. In most cases, compressive, tensile, bending, and other volume strains represent a combination of the simplest types of deformations: linear strain and shear strain. Linear strains are assessed by the rate of relative linear strain, which is equal to the ratio of increment of elementary-macrovolume linear size to the original size, while shear strains are determined by the angle of shear face. In order to determine volume strain, superposition principle is used. In the proposed mathematical model (Bulat \& Slashchov, 2012; Bulat, Slashchov, \& Slashchova, 2014) implemented on the basis of the finite element method, total strain of the model element (strain tensor) is described by the sum of vectors of nodal displacements and divided into spherical and deviation parts. Deviation part of the strain tensor characterizes changed shape of the rock mass elements in the process of the rock disintegration. Spherical part of the strain tensor is determined by the rate of minimum principal normal strains of the model elements, which characterize changes in the pore-fractured area volume and, consequently, its permeability. Since particle compressibility in the rock skeleton is negligibly small in comparison with its overall compressibility, a reasonable assumption is made that deformation of the pore medium is equal to the changed volume of the pore-fracture area.

Principle strains are calculated by the finite element method and by formulas (Gallager, 1984; Fadeyev, 1987) for rock mechanics:

- for zones of elastic strain, by:

$$
\begin{aligned}
& \varepsilon_{1}=0.5\left(\left(\varepsilon^{x}+\varepsilon^{y}\right)+\sqrt{\left(\varepsilon^{x}-\varepsilon^{y}\right)^{2}+4 \gamma^{x y 2}}\right) \\
& \varepsilon_{3}=0.5\left(\left(\varepsilon^{x}+\varepsilon^{y}\right)-\sqrt{\left(\varepsilon^{x}-\varepsilon^{y}\right)^{2}+4} \gamma^{x y 2}\right),
\end{aligned}
$$

where:

$\varepsilon^{x}, \varepsilon^{y}-$ components of the strain tensor along $x$ and $y$ coordinate axes, which are determined by solving matrix of the system stiffness by the finite element method;

$\gamma^{x y}$ - transverse shear strain;

- for zones of inelastic strain, by ultimate maximum principal strains expressed by actual limit tensile of the rock strength and rock physical and mechanical properties:

$$
\varepsilon_{1}^{\lim }=\frac{\sigma_{1}^{l i m}\left(1-v_{i}^{2}\right)}{E\left(1+v \operatorname{ctg} \xi-\frac{1+\sin \phi}{1-\sin \phi}(\operatorname{ctg} \xi+v)\right)},
$$

where:

$\sigma_{1}^{l i m}$ - ultimate maximum principal strains, $\mathrm{MPa}$;

$E$ - modulus of elasticity, $\mathrm{MPa}$;

$v$ - Poisson's ratio;

$\varphi$ - angle of internal friction, deg.

Having the results of the solved equations (11), (12), we obtain vectors which contain values of minimum and maximum components of elastic and inelastic strains. In equation (12), ultimate minimum principal strain $\varepsilon_{3}{ }^{\text {lim }}$ is represented as a function of maximum principal strain in the form of the parameter $\operatorname{ctg} \xi\left(\varepsilon_{1} \operatorname{ctg} \xi=\varepsilon_{3}\right)$ determining the law of plastic flow (when $\xi=\pi / 4$, the flow is equilibrium). Values of principal strains calculated by the finite element method are equal to the actual principal strains corresponding to the deformation model of the medium.

The mathematical modeling was based on analytical schemes of coal-seam longwall mining with no pillar left and with the reuse of preparatory roadways. Several quasistationary states of the rocks stress-strain state were simulated, which determined typical stages of the panel mining. Data, determining transformation of pore-fractured areas in the process of the panel mining, were investigated under two conditions: with homogeneous roof (on the basis of averaged rock physical and mechanical properties (Slashchova, Slashchov, \& Yalanskiy, 2014; Yalanskiy, Sapunova, Slashchov, \& Novikov, 2014) and with layered roof. Within the zones of elastic strain, pore-fractured area compression and tension under the influence of pressure difference in rocks were analyzed. Within the zones of inelastic strain under conditions of ununiform compression of components, directed microcracks (since pores effect weakly the gas seepage) and extended compressed main cracks were analyzed additionally. Within the zones of inelastic strain under conditions of stretching (random falls), open main cracks and rock blocks were analyzed.

Analysis of changes in the rock minimum principal strains (volumes of the pore-fractured area) in the face and formation of zones with different rates of permeability (Fig. 2) shows that, from the side of the coal seam, within the zone of bearing pressure, rocks of the main roof are in the state of repacking, and their gas permeability is low. On the contrary, within the interval of $-10 \ldots+20 \mathrm{~m}$ from the belt heading, they demonstrate maximum decompaction factor and significant disintegration. Therefore, in this zone, gas permeability is very high and can contribute either to gas accumulation or gas migration towards any direction. Beyond the 30...40meter zone, process of hydrostatic pressure recovery starts in the broken rocks. 
(a)

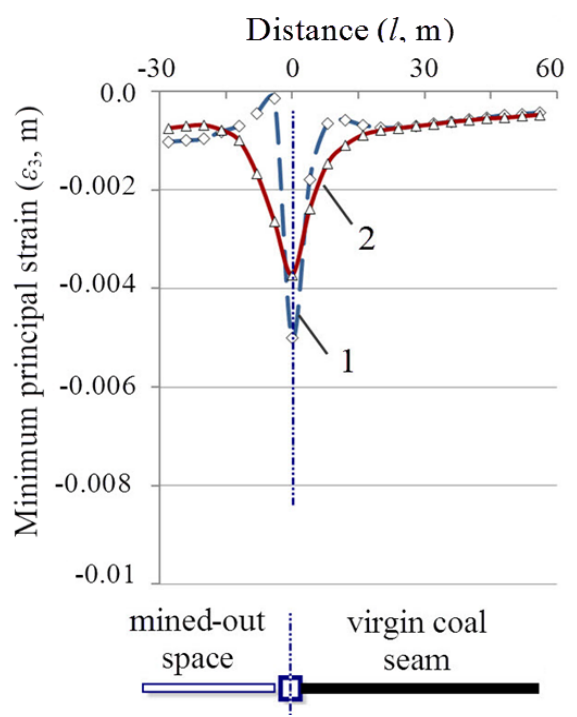

(b)

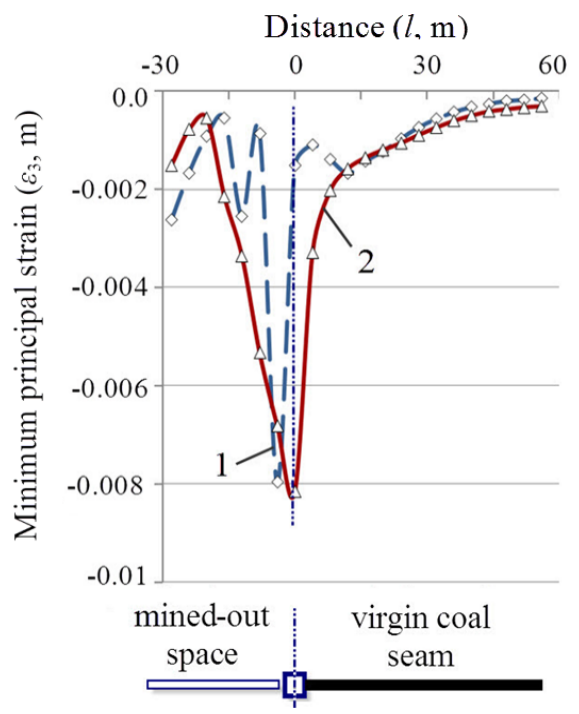

Figure 2. Changes in minimum main strains of the roof (volumes of the pore-fractured area) in the process of coal seam mining: (a) at the level of the longwall face; (b) $30-70 \mathrm{~m}$ after the driven longwall and main roof settling; 1 - deformations of immediate roof at a distance of $3 m$ from the coal seam; 2 - deformations of the main roof at a distance of $9 \mathrm{~m}$ from the coal seam

The layered roof was studied in terms of real properties of rocks, while mining coal seam $m_{3}$ from the deposits of geological Middle Carboniferous suite, which were represented by alternating layers of sandstones, siltstones, and mudstones of varying thickness (Fig. 3). Three main zones, affecting gas flow, were distinguished: zone of random fall behind the longwall, where travel of gas flows was unlimited in any directions (high permeability zone); zone of inelastic strain under ununiform compression of components, where gas passed through the main cracks; zone of high rock pressure in front of the longwall (low permeability), where pores were compressed resulting in low gas permeability of rocks.

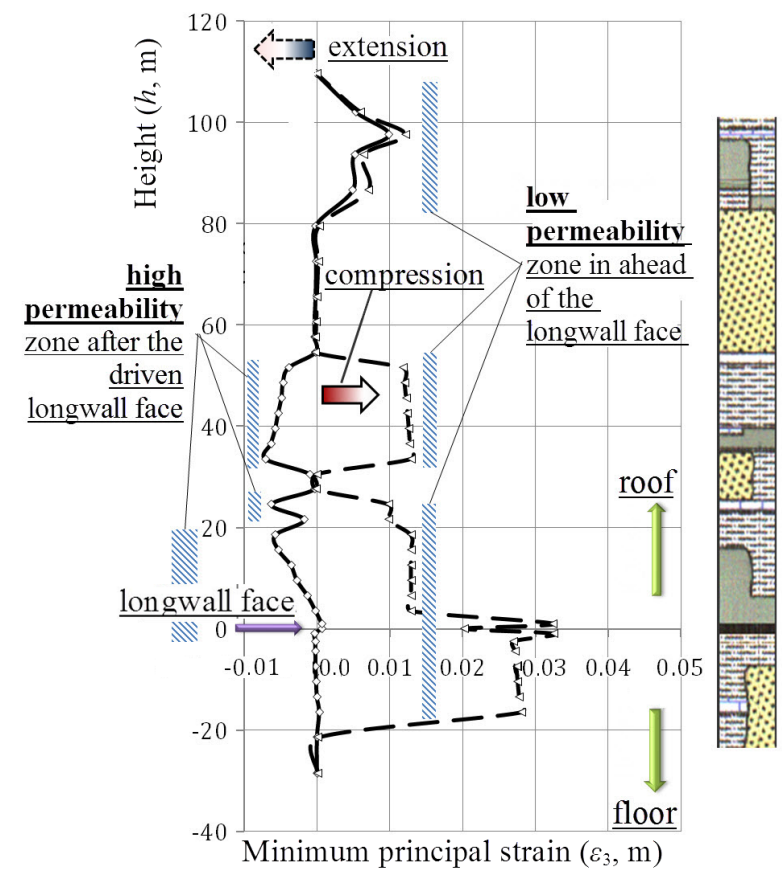

Figure 3. Forecast of changes in the pore-fractured area in the layered rock mass at the border of adjacent longwalls determined by changes in minimum principal strain 83 of the roof and floor layers during the panel mining

The greatest loss of gas flow energy occurred when gas moved across the layered rocks or through the zones of stress concentration (where less number of main cracks were formed), which explained the reduced rate of gas flowing into the roadways directly from the main roof.

\subsection{Forecast of fracture system orientation in the rock mass}

Processes of rock deformation affect structure and volume of pore-fractured area and form areas with gas emission. Determination of the fracture system orientation is required to predict paths for gas flowing from the gas emission areas into the roadways in the working area.

As a result of analytical studies, directions of the two systems of leading cracks occurred during the mining of adjacent longwalls (see black lines in Figure 4) were determined. As it is shown in the diagram of the panel crosssection, systems of almost horizontal cracks are developed in the main roof above the longwall face, where they form additional discontinuities in the mass continuity.

Here, three main zones, affecting gas flow, are distinguished: zone of random fall behind longwall, where travel of gas flows is unlimited in any directions (zones of high permeability, Figure 4, zones 1 and 5); zone of inelastic strain under ununiform compression of components, where gas passes through the main cracks (zones with directed gas flow, Figure 4, zones 2 and 3); zone of high rock pressure in front of the longwall (low permeability), where pores are compressed and, as a result, gas permeability of rocks is significantly reduced.

In the mine roadways, methane content depends primarily on geomechanical processes in the rock mass, since the resulting cracks determine permeability of the rocks along the path of gases seeping from the gas emission sources to the exposed surfaces. 


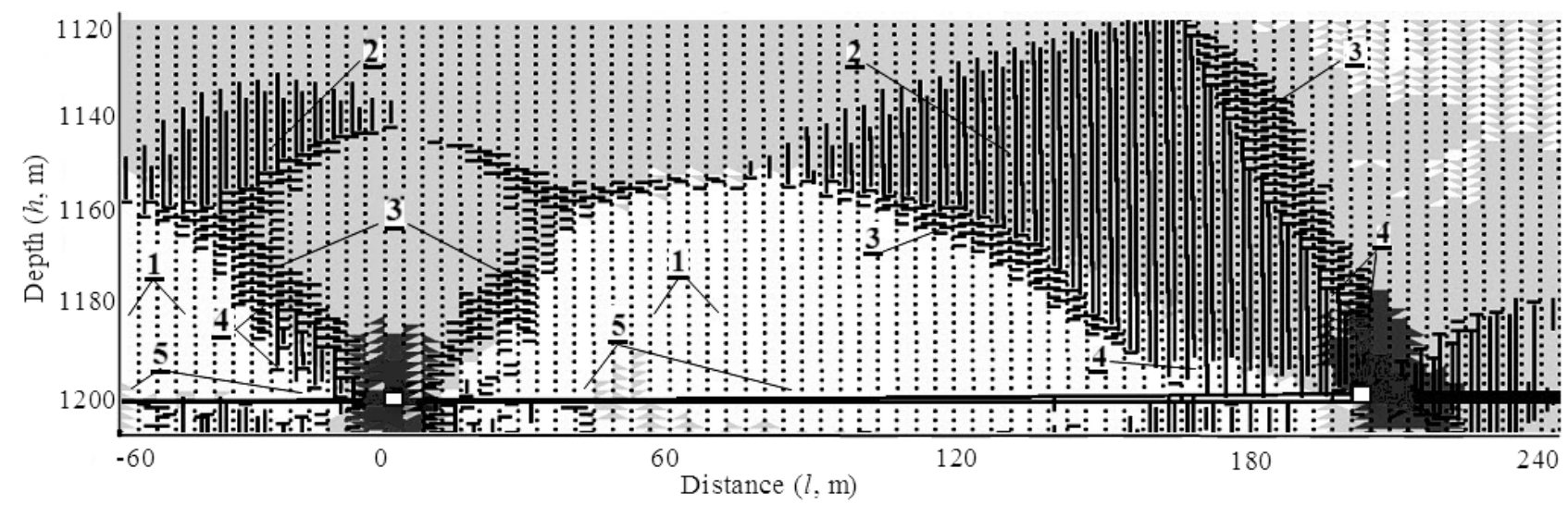

Figure 4. Development of fracture systems during mining the adjacent longwalls: 1 - release zone; 2 - fracture systems orthogonal to the coal seam; 3 - mostly horizontal systems of shear cracks; 4 -formation of block structures within the zone of falls; 5 - zones of random falls

Due to the formation of worked-out areas, rock pressure decreases, and free and previously adsorbed gases are released from the pore-fractured area. Methane demonstrates good diffusibility resulting in its fast penetration through the fractured rocks. It travels under the action of pressure gradients and gas lifting force when pores are filled with water, due to the processes of moisture circulation, heat exchange and others factors.

\subsection{Identification of space and time variations of radon decay product exhalation in the mine roadways}

Under conditions of equal volumetric compression, permeability of rocks and diffusion of air, methane and radon seeped through them are the key informative parameters, by which rate of the rock mass fracturing within the inelastic strain zones can be determined by methods of monitoring from the mine roadways. High penetrability of inert radioactive radon gas explains its property of selective penetration (seeping) through very small pores and microcracks in the rocks. Diffusion of methane gas $\left(\mathrm{CH}_{4}\right)$ is 1.6 times higher than that of air; therefore, similarly to radon, it can penetrate through the porous and fractured rocks. This difference in permeability of methane $\left(K_{\mathrm{CH} 4}\right)$ and inert gas (helium, $K_{\mathrm{He}}$ as the one being closest to radon by its diffusion and migration properties) is confirmed by the comparative dependences constructed and analyzed by the Institute of Geotechnical Mechanics during laboratory studies of coal samples taken in Sukhodolska\#1 and Yasynovska-Hlyboka mines. The measurements were performed at various time intervals starting from the moment when a constant rate of gas flow was fixed in the sample and 22 hours later, during the time when the external load was applied and kept at the same level (Fig. 5).

Change of hydro-pressing force in the samples within the interval from $\sigma_{e}=1 \mathrm{MPa}$ to $\sigma_{e}=6 \mathrm{MPa}$ and with pressure gradient of $\Delta p=0.5 \mathrm{MPa}\left(\Delta p=p_{2}-p_{1}\right)$ results in the decreased permeability of methane $(50 \mathrm{mD})$ and inert gas $(120 \mathrm{mD})$ (Fig. 5a) as well as with pressure gradient of $0.2 \mathrm{MPa}$ (by 80 and $90 \mathrm{mD}$ respectively) (Fig. 5b). When volumetric stresses are within the range of $2-6 \mathrm{MPa}$, permeability of the medium for methane and inert gas decreases by $15-35 \%$, and in absolute values, the inert gas features $2.0-2.7$ times greater diffusion than methane $\left(n=K_{\mathrm{He}} / K_{\mathrm{CH} 4}\right.$, average weighted value of the coefficient is $n=2.4$ ). (a)

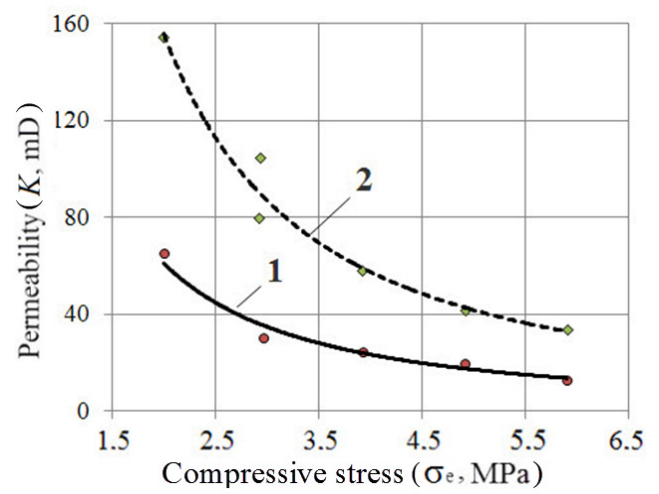

(b)

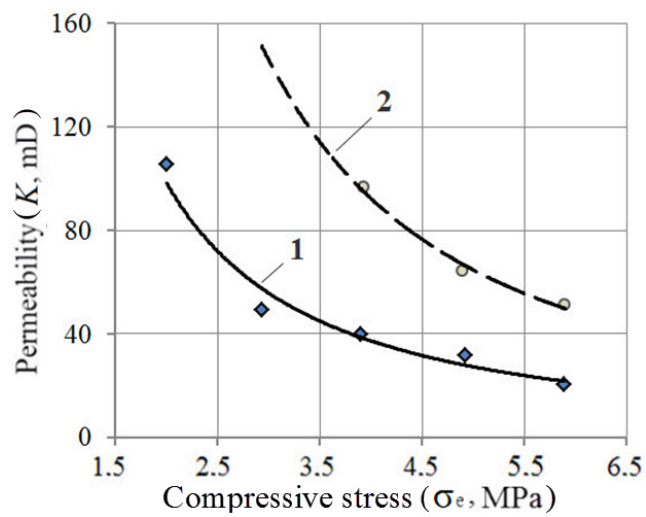

Figure 5. Permeability of coal sample for inert gas and methane under the influence of volumetric compression forces $\sigma_{e}(\mathrm{MPa})$ at different gas pressure gradients $\triangle p:$ (a) $\triangle p=0.5 \mathrm{MPa} \quad\left(\mathrm{K}_{\mathrm{He}}=422 \sigma_{e} e^{-1.4}\right.$; $\left.R^{2}=0.97 ; \quad K_{C H 4}=160 \sigma^{-1.4} ; \quad R^{2}=0.97\right) ;$ (b) $\triangle \mathrm{p}=0.2 \mathrm{MPa} \quad\left(\mathrm{K}_{\mathrm{He}}=837 \sigma_{e}^{-1.6} ; \quad R^{2}=0.99\right.$; $\left.K_{C H 4}=259 \sigma_{e}^{-1.4} ; R^{2}=0.97\right) ; 1-$ methane gas permeability; 2 - inert gas permeability

Analysis of the comparative dependences shows that within the zones of elastic strain of rocks around the roadways under conditions of growing bearing pressure, pores and microcracks are compressed, and permeability of the rocks decreases for all gases. However, due to the high diffusion capacity of inert radioactive aerosols, it becomes possible to fix even minor changes in the rock 
stresses and strains. Quantitative indicators of differences in inert gas and methane permeability make it possible to use new integral criteria to monitor state of the rocks. The obtained data can be used to formalize boundary conditions while solving problems of seepage of methane gas, radon and their decay products into the mine roadways.

That fact is confirmed by the measurement results of radon decay products in the conveyor passage of the eastern sloping longwall (Fig. 6); the measurements showed that within the areas with geological dislocations, concentration of radon decay product of polonium alpha-radiation $\left(\mathrm{Po}^{218}\right)$ increases by more than $2-4$ times comparing to average value in the roadway. Basing upon that criterion, it is proposed to use radiometric monitoring of the mine roadways to detect areas with fracture systems, formed newly as a result of deformation process as one of the elements of method for integrated control of the rock mass state.

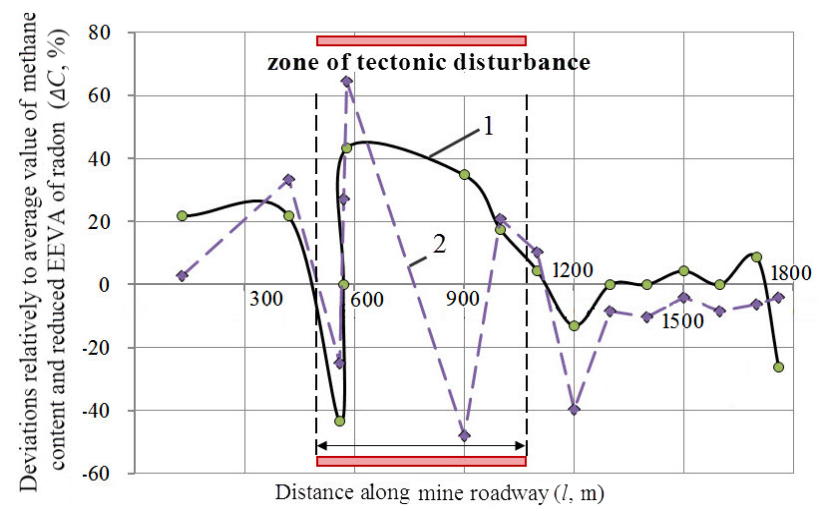

Figure 6. Dynamics of methane $\left(\mathrm{CH}_{4}\right)$ content changing and reduced Equivalent Equilibrium Volume Activity (EEVA) of radon decay product relatively to average value in the mine roadway: 1 -intensity of change in the $\mathrm{CH}_{4}$ reduced concentration; 2 - intensity of change in reduced equivalent equilibrium volume activity of radon

As a result of the rocks disintegration and development of fracture systems, not only increased amount of radon is released within the zone of high rock pressure, but also the number of short-lived isotopes dominates significantly over the long-lived ones. Consequently, processes accompanying the increase in rock pressure intensity occur. Therefore, detecting the areas with intensive emanation activity of radon decay products makes it possible to identify in advance the areas with hidden tectonic disturbances and high stress concentrations in the mine roadways.

\section{CONCLUSIONS}

On the basis of the findings, following scientific results were obtained:

- relationships were formulated, which established interdependence between the parameters of geomechanical process (fracture porosity, angles of the fracture system incidence and strike) and parameters of gas-dynamic process (intensity, flow rates, and direction of gas flowing), which can be integrated into information systems for preventive control of the state of working environment in the mines;
- rational parameters were validated for geomechanical and gas-dynamic processes in the rock mass: characteristics of the pore-fractured area volume, location and permeability, which are the key parameters to determine rate of gas flow and paths for gas seeping. On the basis of the obtained parameters for technogenic main-fracture system orientation and spherical part of the strain tensor, patterns of changes in the pore-fractured area shape and volume were established for various stages of adjacent longwalls mining;

- parameters of changes in $\alpha$-radiation activity of radon decay products, methane concentrations and their relationship depend on changes in the fracturing pattern in the rocks near the roadway contour, and can be used to predict geomechanical and gas-dynamic processes in the rock mass in the process of mining activity.

Those scientific results were used for developing analytical-and-experimental method to monitor safety of working environment in the mines.

\section{ACKNOWLEDGEMENTS}

The authors express their gratitude to the Director of the Institute of Geotechnical Mechanics named by N. Poljakov of National Academy of Sciences of Ukraine, Academician of the National Academy of Sciences of Ukraine, Professor A.F. Bulat for providing technical and informational support for the research.

\section{REFERENCES}

Bulat, A.F., \& Slashchov, I.M. (2012). Development of computer systems mathematical modeling geomechanical processes. Geo-Technical Mechanics, (99), 16-27.

Bulat, A.F., Perepelytsya, V.H., Yalanskyy, A.A., Palamarchuk, T.A., Yefremov, O.I., \& Zabolotniy, A.H. (2013). Theoretical justification for the application of the emission radiation method as a factor in the production control of the rock massif. Geo-Technical Mechanics, (66), 3-14.

Bulat, A.F., Slashchov, I.N., \& Slashchova, O.A. (2014). Interdependencies between geomechanical processes and emission of methane and radon decay products into underground workings of the coal mines. Geo-Technical Mechanics, (114), 272-286.

Bulat, A.F., Slashchov, I.M., \& Slashchova, O.A. (2017). Evaluation methods of interconnected geomechanical and gas dynamic processes in the rock massif for the systems of working medium control in the mines. Geo-Technical Mechanics, (59), 34-44.

Fadeyev, A.B. (1987). The finite element method in geomechanics. Moscow, Russia: Nedra.

Gallager, R. (1984). Finite element analysis. Fundamentals. Moscow, Russia: Nauka.

Ikonnikov, M.Yu., Ikonnikov, Yu.R., Slashchova, O.A., Slashchov, I.M., \& Yalanskiy, A.O. (2015). Mathematical modeling in solving problems of evaluating the efficacy and safety of mining operations. Dnipropetrovsk, Ukraine: Natsionalnyi Hirnychyi Universytet.

Ministry of Energy and Coal Industry of Ukraine. (2018). Retrieved from http://mpe.kmu.gov.ua/minugol/control/uk/publish

Shevchenko, V.G. (2016). Developing methods for increasing readiness of the managers of coal mine divisions to accident-free operation according to quantitative estimations of their personality characteristics. Naukovyi Visnyk Natsionalnoho Hirnychoho Universytetu, 6(156), 114-119.

Slashchov, I.M. (2013). The use of information technology to increase the efficiency and safety of mining operations. Coal of Ukraine, (2), 40-43. 
Slashchov, I.M., Shevchenko, V.G., \& Slashchov, A.I. (2013). Optimized information system for on-line predicting of geomechanical process behavior and ensuring proper decision-making on the mine safety. Geo-Technical Mechanics, (112), 129-144.

Slashchova, O.A., Slashchov, I.M., \& Yalanskiy, A.O. (2014). Features solutions for problems of geomechanical watery gas-saturated rock massif. Geo-Technical Mechanics, (115), 232-244

Slashchov, A.I. (2016). Justification of the parameters of the information system assuring the underground mining safety. Naukovyi Visnyk Natsionalnoho Hirnychoho Universytetu, (1), 77-85.

Yalanskiy, A.A., Sapunova, I.O., Slashchov, A.I., \& Novikov, L.A. (2014). Justification of the initial parameters for geomechanical processes modeling in problems of safety assessment of mine workings maintenance. Geo-Technical Mechanics, (119), 282-295.

Zienkiewicz, O.C., Taylor, R.L., \& Zhu, J.Z. (2005). The finite element method: its basis and fundamentals. London, United Kingdom: Butterworth-Heinemann.

\section{ПРОГНОЗ ПОТЕНЦИИНО НЕБЕЗПЕЧНИХ ПРОЯВІВ ГІРСЬКОГО ТИСКУ У ВИРОБКАХ ШАХТ ІЗ ВИКОРИСТАННЯМ ІНФОРМАЦИЙНИХ ТЕХНОЛОГІЙ І МЕТОДІВ РАДІОМЕТРИЧНОГО КОНТРОЛЮ}

\section{I. Слащов, В. Шевченко, В. Курінний, О. Слащова, О. Яланський}

Мета. Знизити ризики виникнення аварійних і травмонебезпечних ситуацій в шахтах шляхом вдосконалення методів прогнозу напружено-деформованого стану масиву порід із використанням інформаційних систем та виявлення локацій тріщин у гірничих виробках методом радіометричного контролю.

Методика. Аналіз і узагальнення експериментальних даних; математичне моделювання геомеханічних і фільтраційних процесів методом скінченних елементів; шахтні дослідження змін активності $\alpha$-випромінювань окремих ізотопів радону в атмосфері гірничих виробок стандартними методами та апаратурою радіометричного контролю; статистична обробка результатів вимірювань.

Результати. Отримані співвідношення, що встановлюють взаємозв'язки параметрів геомеханічного процесу (тріщиною пористістю, кутами падіння і простягання систем тріщин) з параметрами газодинамічного процесу (інтенсивністю, витратами та напрямком переміщення газів). Запропоновано математичну модель на базі методу скінченних елементів, в якій прийнято обгрунтоване припущення, що деформація пористого середовища дорівнює зміні об'ємів порово-тріщинного простору. У моделі девіаторна частина тензора деформацій визначає зміни форми елементів породного масиву в процесі руйнування. Кульова частина тензора деформацій характеризує зміни об'єму і проникності порово-трещинного простору та визначається величиною мінімальних головних деформацій елементів моделі. Обгрунтовані параметри розташування, об’ємів і проникності порово-тріщинного простору в масиві порід. Шахтними дослідженнями встановлено, що в місцях дислокації геологічних порушень концентрація дочірнього продукту розпаду радону $\alpha$-випромінювання полонію $\left(\mathrm{Po}^{218}\right)$ зростає більш ніж в 2 - 4 рази по відношенню до середнього по виробці значення. На базі вказаного критерію запропоновано використовувати радіометричний моніторинг гірничих виробок для виявлення локацій новоутворених в процесі деформування систем тріщин в якості одного з елементів методу комплексного контролю стану породного масиву.

Наукова новизна. Вперше на базі параметрів орієнтації систем тріщин техногенного походження й кульової частини тензора деформацій встановлені закономірності змін форми та об'ємів порово-тріщинного простору на різних етапах відпрацювання суміжних лав. Подальший розвиток отримав метод контролю безпечного стану гірських порід, який відрізняється використанням встановлених взаємозв'язків між змінами параметрів систем тріщин та змінами активності $\alpha$-випромінювань окремих ізотопів радону, концентрацій метану і їх співвідношень.

Практична значимість. Наукові результати використані при розробці аналітико-експериментального методу контролю безпеки виробничого середовища шахт.

Ключові слова: геомеханічні прочеси, проникність, фільтрація, радіометричний контроль, моделювання масиву порід, прогнозування геомеханічного стану

\section{ПРОГНОЗ ПОТЕНЦИАЛЬНО ОПАСНЫХ ПРОЯВЛЕНИЙ ГОРНОГО ДАВЛЕНИЯ В ВЫРАБОТКАХ ШАХТ С ИСПОЛЬЗОВАНИЕМ ИНФОРМАЦИОННЫХ ТЕХНОЛОГИЙ И МЕТОДОВ РАДИОМЕТРИЧЕСКОГО КОНТРОЛЯ}

\section{И. Слащев, В. Шевченко, В. Куренной, Е. Слащева, А. Яланский}

Цель. Снизить риски возникновения аварийных и травмоопасных ситуаций в шахтах путем совершенствования методов прогноза напряженно-деформированного состояния массива пород с использованием информационных систем и выявления локаций образовавшихся трещин в горных выработках методом радиометрического контроля.

Методика. Анализ и обобщение экспериментальных данных; математическое моделирование геомеханических и фильтрационных процессов методом конечных элементов; шахтные исследования изменений активности $\alpha$-излучений отдельных изотопов радона в атмосфере горных выработок стандартными методами и аппаратурой радиометрического контроля; статистическая обработка результатов измерений.

Результаты. Получены соотношения, устанавливающие взаимосвязи параметров геомеханического процесса (трещинной пористостью, углами падения и простирания систем трещин) с параметрами газодинамического процесса (интенсивностью, расходами и направлением перемещения газов). Предложена математическая модель на базе метода конечных элементов, в которой принято обоснованное допущение, что деформация пори- 
стой среды равна изменению объема порово-трещинного пространства. В модели девиаторная часть тензора деформаций определяет изменение формы элементов породного массива в процессе разрушения. Шаровая часть тензора деформаций характеризует изменения объема и проницаемости порово-трещинного пространства и определяется величиной минимальных главных деформаций элементов модели. Обоснованы параметры расположения, объемов и проницаемости порово-трещинного пространства в массиве пород. Шахтными исследованиями установлено, что в местах дислокации геологических нарушений концентрация дочернего продукта распада радона $\alpha$-излучения полония $\left(\mathrm{Po}^{218}\right)$ возрастает более чем в $2-4$ раза по отношению к среднему по выработке значению. На базе указанного критерия предложено использовать радиометрический мониторинг горных выработок для выявления локаций вновь образовавшихся в процессе деформирования систем трещин в качестве одного из элементов метода комплексного контроля состояния породного массива.

Научная новизна. Впервые на базе параметров ориентации систем трещин техногенного происхождения и шаровой части тензора деформаций установлены закономерности изменений формы и объемов порово-трещинного пространства на различных этапах отработки смежных лав. Дальнейшее развитие получил метод контроля безопасного состояния горных пород, который отличается использованием установленных взаимосвязей между изменениями параметров систем трещин и изменениями активности $\alpha$-излучения отдельных изотопов радона, концентраций метана и их соотношений.

Практическая значимость. Научные результаты использованы при разработке аналитико-экспериментального метода контроля безопасности производственной среды шахт.

Ключевые слова: геомеханические прочессы, проницаемость, фильтрация, радиометрический контроль, моделирование массива пород, прогнозирование геомеханического состояния

\section{ARTICLE INFO}

Received: 25 January 2019

Accepted: 22 September 2019

Available online: 3 October 2019

\section{ABOUT AUTHORS}

Ihor Slashchov, Candidate of Technical Sciences, Senior Researcher of the Department of Mineral Mining at Great Depths, Institute of Geotechnical Mechanics named by N. Poljakov of National Academy of Sciences of Ukraine, 2a Simferopolska St, 49005, Dnipro, Ukraine. E-mail: IMSlashchov@,nas.gov.ua

Volodymyr Shevchenko, Doctor of Technical Sciences, Professor, Scientific Secretary of the Institute of Geotechnical Mechanics named by N. Poljakov of National Academy of Sciences of Ukraine, 2a Simferopolska St, 49005, Dnipro, Ukraine. E-mail: V.Shevchenko@nas.gov.ua

Volodymyr Kurinnyi, Doctor of Technical Sciences, Professor of the Department of Physics, Dnipro University of Technology, 19 Yavornytskoho Ave, 49005, Dnipro, Ukraine. E-mail: pgalpha.1td@gmail.com

Olena Slashchova, Candidate of Technical Sciences, Senior Researcher of the Department of Mineral Mining at Great Depths, Institute of Geotechnical Mechanics named by N. Poljakov of National Academy of Sciences of Ukraine, 2a Simferopolska St, 49005, Dnipro, Ukraine. E-mail: OASlashchova@,nas.gov.ua

Oleksii Yalanskyi, Candidate of Technical Sciences, Associate Professor of the Department of Electric Drive, Dnipro University of Technology, 19 Yavornytskoho Ave, 49005, Dnipro, Ukraine. E-mail: yalanskiy.o.a@gmail.com 